\title{
A11101 730307
}

\section{Reference}

NBS

Publi -

matreations

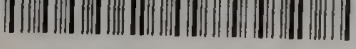

Al】105 157763

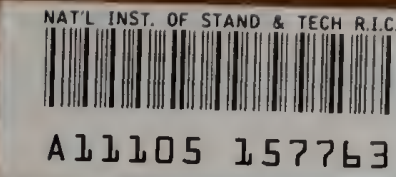

ATE 3-06 Tentative Seismie Provisions

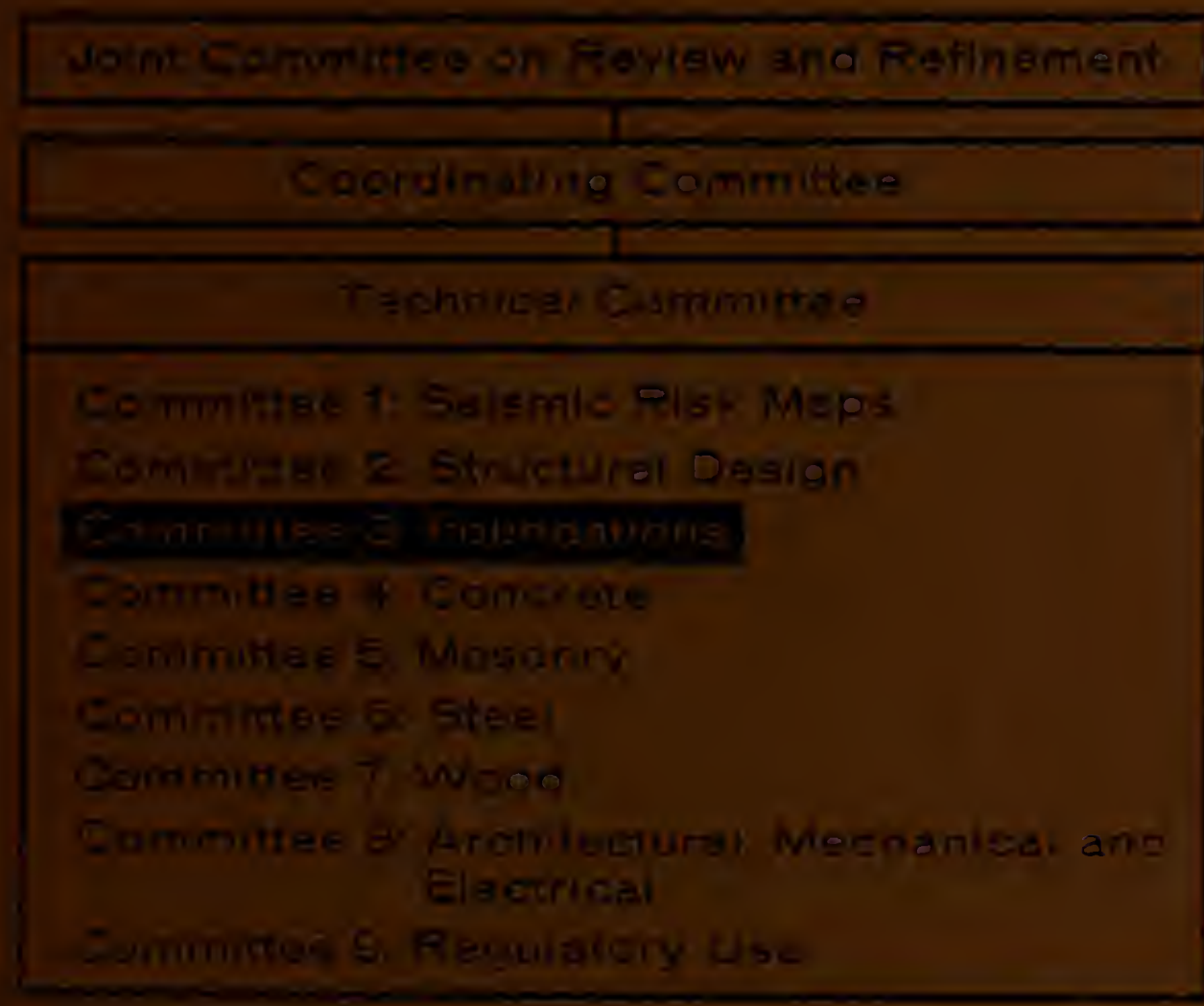

Report of Technical Committee 3: Foundations

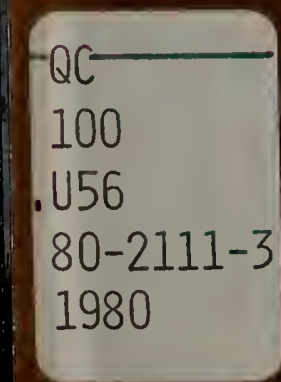


REVIEW AND REFINEMENT OF ATC 3-06

TENTATIVE SEISMIC PROVISIONS

Report of Technical Committee 3: Foundations

Richard Simon, Chairman, Association of Soil and Foundation Engineers

Lawrence Salomone, Secretary, National Bureau of Standards

James G. LaBastie, American Society of Civil Engineers

William Travis, Structural Enginners Association of California

Joseph V. Tyrre11, Interagency Committee on Seismic Safety in Construction

Henry Degenkolb, Applied Technology Council

Leroy Crandall, Building Seismic Safety Council

Prepared for use by the:

Building Seismic Safety Council

Sponsored by:

Federal Emergency Management Agency

Center for Building Technology

National Bureau of Standards

Washington, D.C. 20234

October 1980

U.S. DEPARTMENT OF COMMERCE, Phillip M. Klutznick, Secretary Luther H. Hodges, Jr., Deputy Secretary

Jordan J. Baruch, Assistant Secretary for Productivity, Technology and Innovation

NATIONAL BUREAU OF STANDARDS, Ernest Ambler, Director 

The Tentative Provisions for the Development of Seismic Regulations for Buildings were developed by the Applied Technology Council to present, in one comprehensive document, current state-of-knowledge pertaining to seismic engineering of buildings. The Tentative Provisions are in the process of being assessed by the building community. This report is one of a series of reports that documents the deliberations of a group of professionals jointly selected by the Building Seismic Safety Council and the National Bureau of Standards and charged with reviewing the Tentative Provisions prior to conducting trial designs.

This report documents the activities of Technical Committee 3: Foundations. Other committee reports are similarly available. The task of Technical Committee 3 was to review and refine Chapter 6, Soil-Structure Interaction and Chapter 7, Foundation Design Requirements in the ATC report (NBS SP-510) entitled, "Tentative Provisions for the Development of Seismic Regulations for Buildings." Two meetings were held. The opening meeting of the group was on December 11, 1979, and the concluding meeting was on February 5, 1980. The minutes of these meetings and the findings/recommendations of Technical Committee 3 are presented in this report. These recommendations were made to the parent group, the Joint Committee on Review and Refinement, and their action on these recommendations is documented in a companion report.

Keywords: Buildings; design; earthquakes; engineering; foundations; professional practice; provisions; soil-structure interaction; standards 


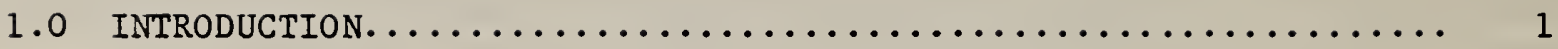

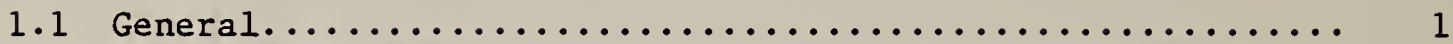

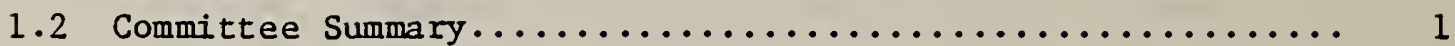

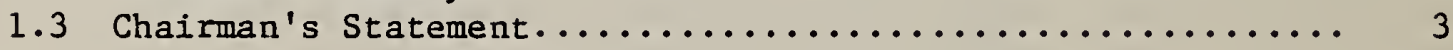

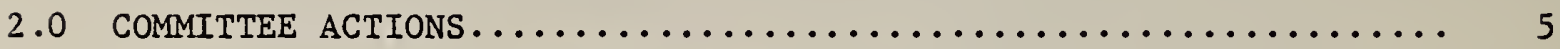

2.1 Recommendations for Change.................... 5

2.2 Recommendations for Trial Design.................. NONE

2.3 Recommendations for Commentary................... NONE

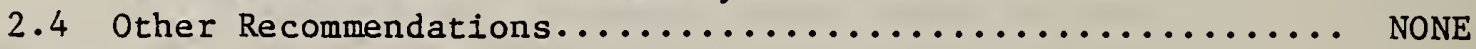

3.0 COMMITTEE RECORDS ........................... 12

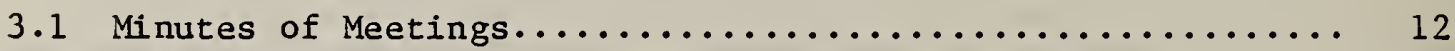

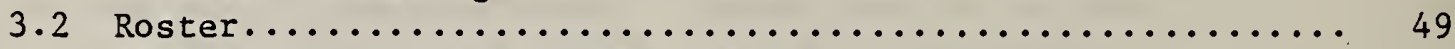

3.3 Selected Committee Correspondence and Applied

Technology Council Comments.................... NONE 


\subsection{INTRODUCTION}

\subsection{Genera 1}

The Tentative Provisions for the Development of Seismic Regulations were developed by the Applied Technology Council (AIC) in an effort that included a wide range of experts in the actual drafting of the provisions. Two external review drafts were circulated to a large portion of the interested and informed community of eventual users. However, because the Tentative Provisions were innovative, doubts about them existed. Consequenty, an attempt was made to investigate these doubts and to improve the Tentative Provisions where possible before an expensive assessment of the Tentative Provisions was undertaken by conducting trial designs.

This review and refinement project was planned and conducted by the National Bureau of Standards with the advice and approval of the Building Seismic Safety Council, a private sector organization formed in 1979 for the purpose of enhancing public safety by providing a national forum to foster improved seismic safety provisions for use by the building community.

The assessment of the Tentative Provisions was performed using the committee structure shown in figure l. Nine Technical Committees were formed with interests that collectively cover the Tentative Provisions. The Joint Committee on Review and Refinement consists of all voting members of the Technical Committees. The chairmen of the Technical Committees form a Coordinating Committee.

Membership of each Technical Committee is made up of representatives of organizations that have particular interest in the Tentative Provisions; the participants are listed in the committee membership section of this report.

In addition to the voting members, each Technical Committee includes a non-voting member from each of the following organizations: The Applied Technology Council (ATC), the Building Seismic Safety Council (BSSC) and the National Bureau of Standards (NBS). The ATC representative served as a technical resource to the committee since he was closely involved with the development of the provisions of interest to the committee. The NBS representative was the technical secretary throughout the effort. The BSSC representative provided a link with the Building Seismic Safety Council, which will be involved in trial designs and evaluations.

\subsection{Committee Sumnary}

This report documents the activities of Technical Committee 3: Foundations. Other committee reports are similarly available.

The task of Technical Committee 3 was to review and refine Chapter 6 , SoilStructure Interaction and Chapter 7 , Foundation Design Requirement, in the ATC report (NBS SP-510) entitled "Tentative Provisions for the Development of Seismic Regulations for Buildings." Two meetings were held. The opening meeting of the group was on December 11, 1979 at the National Bureau of Standards in Building 226, Room B-113. The topics discussed included: 


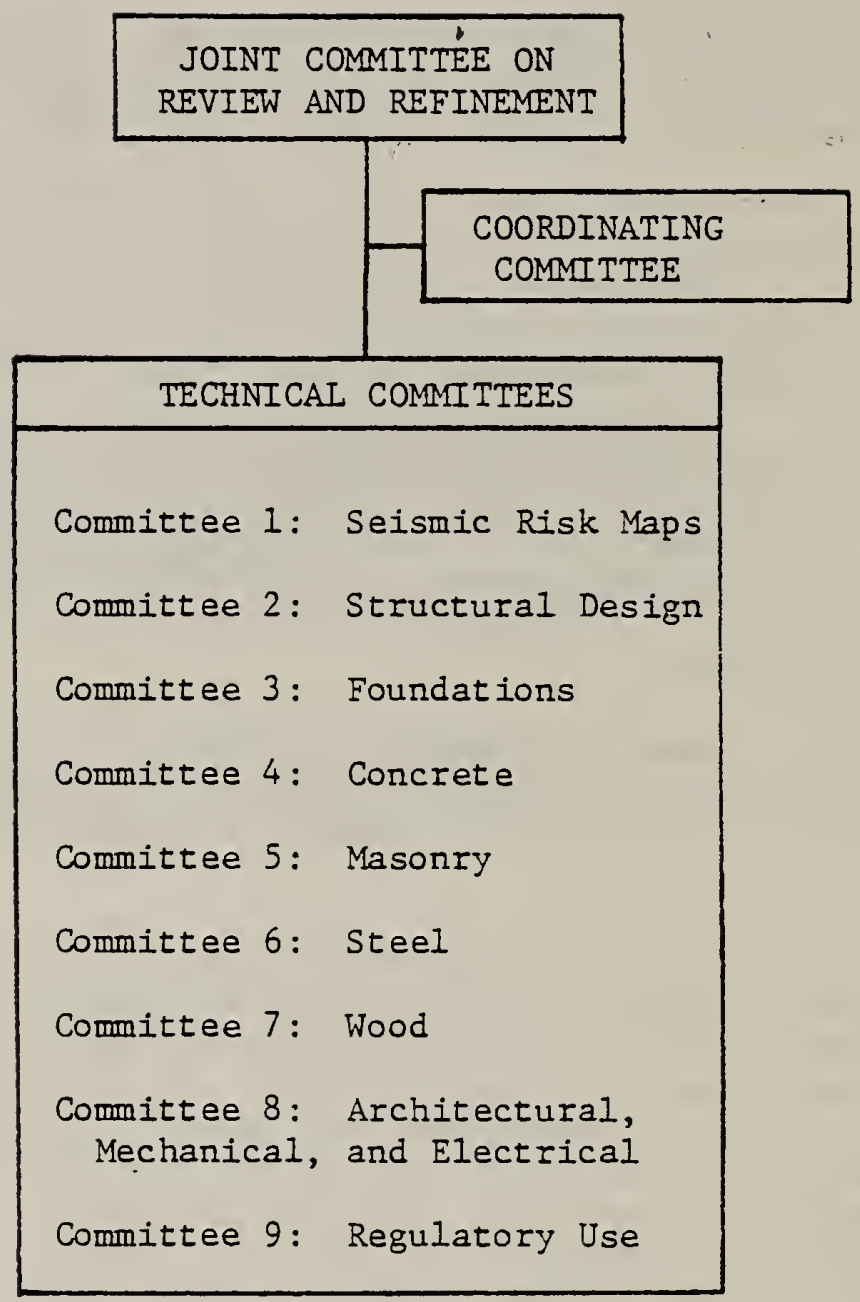

Figure 1: Committee Structure 
1) Introduction and Orientation by NBS Secretary

2) Selection of Chairman

3) Selection of Representative to Committee 2

4) Selection of Date and Location for Next Meeting

5) Establishment of Work Plan and Preliminary Discussion of Chapters 6 and 7

The minutes of the opening meeting are provided in Section 3 of this report.

The second meeting of the group was held on February 15, 1980 at Law Engineering Testing Company, 109 Inverness Drive East, Englewood, Colorado. The meeting served as a workshop to discuss comments received by February 15 , 1980 on Chapters 6 and 7 and to develop recommendations for revising these chapters. Comments were provided to the members of the committee in letters from Lawrence Salomone to members of Technical Committee 3 dated January 16 and January 31 , 1980. Also, late comments received prior to February 15, 1980 meeting were distributed to committee members at the opening of the second meeting .

The second meeting was conducted in the following manner:

1) Each of the comments received were discussed and a final position of the committee developed. The final position consisted of a recommendation for change for the section in question or a recommendation that the section not be modified. was taken.

2) Following development of the final position of the comittee a vote

The results of this meeting and the items voted on are presented in detail in the minutes of the second meeting provided in section 3. With the completion of Meeting 2 the review of Chapters 6 and 7 by Technical Committee 3 was completed. The recommendations of Technical Committee 3 are presented in Section 2 .

\subsection{Chairman's Statement}

In adopting positions concerning the various sections covered in Chapters 6 and 7 of the tentative provisions, the Committee tried to improve clarity and specificity of the clauses (e.g.: Section 7.2.2, Paragraph 非 - changing "at the elastic limit" to "at acceptable strains" to describe allowable stress on soil). Where analytical developments or concepts permit a better description of the desired structural performance, refined definitions have been recommended (e.g.: require piles to sustain soil-determined displacements rather than specify that the piles resist flexure induced by lateral soil pressures).

With respect to design of piles for earthquake, the Committee adopted a position based primarily on the experiences gained following the San Fernando and Anchorage earthquakes. For this reason, the Committee recommended phrases that stress the importance of providing a ductile connection and a ductile pile section in the vicinity of the pile cap. Since precast concrete piles exhibited unsatisfactory performance in some instances in the past, extra conservatism was judged to be appropriate for their use. 
Finally, the Committee considered the Chapter on soil-structure interaction. The discussion was wide ranging, but a strong consensus was reached. The provisions of Chapter 6 are so complex that they are not effective in implementing a new concept. The equations could not be applied by practicing engineers in general without an extraordinary risk of error. The practicing engineer would have little "feel" for what he was calculating. Finally, there are few or no prototype observations that would justify the use of this sophisticated procedure. The Committee recommended that Chapter 6 be deleted from the Provisions at this stage. A compromise position stressing the optional nature of the Chapter was developed by the coordinating committee (Committee 10) as contained on the full committee ballot. Committee 10 accepted that the deletion of the Chapter 6 provisions should be reconsidered following a specific evaluation of their effect during the trail design phase. 


\subsection{COMMITTEE ACTIONS}

\subsection{Recommendations for Change}

In this section the changes to Chapters 6 and 7 proposed by Technical Committee $\#_{3}$ are presented. These changes have been unanimously adopted by the committee members, i.e. there were four affirmative votes. It should also be pointed out that Joseph V. Tyrrell of the Interagency Committee on Seismic Safety in Construction voted affirmative with reservations for Ballot Item 8e. This item involved Section 7.4.4(A) on page 74 of the ATC report, which the committee decided not to modify. Mr. Tyrrell indicated that he did not want this reservation to be voted on by the committee but merely wanted to state for the record that he recommends that "for caissons greater than 30" diameter, minimum reinforcement (steel ratio) should be .0020." Because the committee decided not to modify this item in Section $7.4 .4(\mathrm{~A})$ in their ballot for no change, the item in question does not appear in the following pages. 


\section{PROPOSED CHANGE}

TECHNICAL COMMITTEE: \#3, FOUNDATIONS

COMMITTEE ITEM NUMBER:

ATC-3-06 SECTION REFERENCE: 3.2 .1

The last paragraph in Section 3.2 .1 should be changed to read "In locations where the soil properties are not known in sufficient detail to determine the soil profile type or where the profile does not fit any of the three types, Soil Profile $S_{2}$ or Soil Profile $S_{3}$ shall be used depending on whichever soil profile type results in the higher value of seismic coefficient, $\mathrm{C}_{S}$, as determined in Section 4.2 .1 .

FINAL BALLOT:

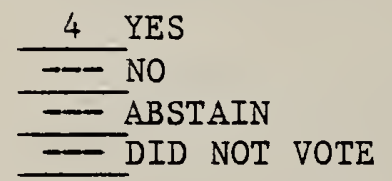

COMMENT ON PROPOSED CHANGE :

Soil Profile Type $S_{2}$ is much better than Type $S_{3}$. Section 3.2 .1 suggests soil profile type $S_{2}$ when the soil properties are not known. This did not seem logiçal. Hence the proposed change was recommended. 
TECHNICAL COMMITTEE: \#3, FOUNDATIONS COMMITTEE ITEM NUMBER: $4 \mathrm{e}$ ATC-3-06 SECTION REFERENCE: $\mathbf{7 . 2 . 2}$

The last sentence in Section 7.2 .2 should read "For the load combination including earthquake as specified in Section 3.7, the soil capacities must be sufficient to resist loads at acceptable strains considering both the short time of loading and the dynamic properties of the soil.

FINAL BALLOT:

$$
\begin{aligned}
& 4 \text { YES } \\
& -- \text { NO } \\
& -- \text { ABSTAIN } \\
& -- \text { DID NOT VOTE }
\end{aligned}
$$

COMMENT ON PROPOSED CHANGE :

Soils are inherently inelastic materials. To specify stressing below the elastic limit is practically without meaning. Hence, the term "elastic limit" should be replaced with the phrase, "to resist loads at acceptable strains". 
TECHNICAL COMMITTEE: \#3, FOUNDATIONS

COMMITEE ITEM NUMBER: $7 \mathrm{e}$

ATC-3-06 SECTION REFERENCE: 7.5 .2

The first sentence in Section 7.5 .2 should be changed to read "Individual spread footings unless founded directly on rock, as defined in Section 3.2.1(1), shall be interconnected by ties".

FINAL BALLOT : $\quad 4$ YES

4 YES
-- NO
-- ABSTAIN
-- DID NOT VOTE

COMMENT ON PROPOSED CHANGE :

The comment was made that it is overly conservative to require structural ties between pile caps equal to $25 \%$ of the maximum vertical load for a Category B structure. This conservatism is amplified in the commentary of this paragraph where it states, "Lateral soil pressure on pile caps is not a recommended method; and if the soil is soft enough to require ties, little reliance can be placed on soft-soil passive pressure to restrain relative displacement under dynamic conditions." There are many cases in which the use of piles is dictated by deep soil deposits and the near surface materials are relatively stiff and strong (such as compact or dense gravels and sands overlying soft clays or controlled, compacted fill over clays or organic soils. In these cases, it would seem reasonable to permit at least a portion of the lateral tie resistance between the pile caps to be provided by lateral soil resistance with some guidance provided. In light of these considerations and after discussing the terminology that would be appropriate, the committee agreed to recommend the change shown above. 
TECHNICAL COMMITTEE: \#汪, FOUNDATIONS

COMMITTEE ITEM NUMBER: $\underline{9 \mathrm{e}}$

ATC-3-06 SECTION REFERENCE: 7.4 .4

At the end of paragraph 2 of Section 7.4.4 (before Item A) the following sentence should be added, "Where special reinforcement at the top of the pile is required alternative measures for containing concrete and maintaining ductility will be permitted provided due consideration is given to forcing the hinge to occur in the contained section.

FINAL BALLOT:

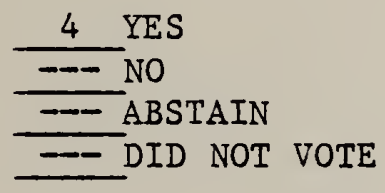

COMMENT ON PROPOSED CHANGE:

The committee discussed possible designs for the connection at the top of the pile. It was agreed that the intent was to put the ductile section where the hinge would form. Considering this fact and the comments received, the proposed change was recommended. The minority view as expressed in a comment from Committee 4 to use an exposed strand was rejected by tine committee because it was judged that one could not manufacturer a ductile connection between the pile and the pile cap using steel strand. Furthermore, it is at the point where the pile is connected to the pile cap that the greatest damage was observed during the San Fernando and Alaskan earthquakes. 


\section{REVIEW AND REFINEMENT OF TENTATIVE SEISMIC PROVISIONS}

\section{PROPOSED CHANGE}

TECHNICAL COMMITTEE: 非3, FOUNDATIONS

COMMITTEE ITEM NUMBER: $10 \mathrm{e}$

ATC-3-06 SECTION REFERENCE: $7.5 \cdot 3(\mathrm{c})$

The last sentence in Section 7.5.3(c) should be revised to read, "Precast concrete and prestressed concrete piling shall be designed to withstand maximum imposed curvatures resulting from a dynamic analysis of the soil profile."

FINAL BALLOT: 4 YES

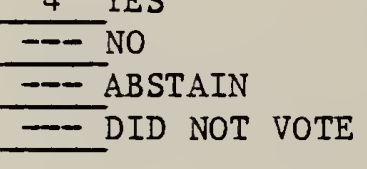

COMMENT ON PROPOSED CHANGE :

The basis for the proposed change was that prestressed precast concrete piling can withstand considerable curvature and through proper detailing confinement and ductility can be provided. 


\section{PROPOSED CHANGE}

TECHNICAL COMMITTEE: 非, FOUNDATIONS

COMMITTEE ITEM NUMBER: $12 \mathrm{e}$ ATC-3-06 SECTION REFERENCE : Chapter 6

Chapter 6 should be deleted.

FINAL BALLOT:

$$
\begin{aligned}
& 4 \text { YES } \\
& -- \text { NO } \\
& -- \text { ABSTAIN } \\
& -- \text { DID NOT VOTE }
\end{aligned}
$$

COMMENT ON PROPOSED CHANGE :

After reviewing Chapter 6 and thoroughly examining the procedures therein, the committee felt strongly that the provisions were not effective in implementing a new concept. Chapter 6 is too complicated for the practicing engineer and it is not justified based on field observations. The sophistication of the analysis is inconsistent with the accuracy of the results and the complexity masks the understanding of the performance of the soil structure system. Further documentation for deletion of Chapter 6 is provided in the minutes for the February 15, 1980 meeting (attachments). 


\subsection{COMMI TTEE RECORDS}

\subsection{Minutes of Meetings}

Committee 3 held two meetings. The opening meeting was on December 11 , 1979 at the National Bureau of Standards in Building 226, Room B113. The second and final meeting was on February 15, 1980 at Law Engineering Testing Company, 109 Inverness Drive East, Englewood, Colorado. The minutes for these meetings are provided in this section. Included in the minutes for the February 15, 1980 meeting are the items which were voted on by Committee 3 and the ballot which was used to document the votes of each member. 


\section{Minutes of 1st Meeting}

of

Technical Comittee No. 3 on Foundations

Eor

Review and Refinement of

Tentative Seismic Provisions (ATC-3-06)

at

National Bureau of Standards

December 11, 1979

\section{Introduction}

On December 11, 1979 a meeting was held at the National Bureau of Standards in Building 226, Room B113 with the members of ATC Review and Rerinement Committee No. 3, Foundations. This was the opening meeting of the group assembled for reviewing and refining Chapter 6, Soil-Structure Interaction, and Chapter 7, Foundation Design Requirements, in the AIC report (NBS SP-510) entitled "Tentative Provisions for the Development of Seismic Regulations for Buildings". The topics discussed included:

1) Introduction and Orientation by NBS Secretary

2) Selection of Chairman

3) Selection of Representative to Committee 2

4) Selection of Date and Location for Next Meeting

5) Establishment of Work Plan and Preliminary Discussion of Chapters 6 and 7

The participants in the meeting are listed in Table 1, List of Participants. With the exception of the ATC representative, Henry Degenkolib, and the Building Seismic Safety Council representative who had not been selected as of December 11, 1979, all members of Comittee 3 attended the opening meeting. To aid in the review of Chapters 6 and 7 , the following handouts were provided: 
1) List of Members of ATC Review and Refinement Committee No. 3 (Table: 2)

2) ATC report (NBS SP-510) entitled "Tentative Provisions for the Development of Seismic Regulations for Buildings"

3) NBS Technical Note 1100 entitled "Analysis of Tentative Seismic Design Provisions for Buildings"

4) Work Plan for Review and Refinement of Tentative Seismic Provisions dated $11 / 27 / 79$

5) Edward 0. Pfrang's letter to the Participants on the Review and Refinement of Tentative Seismic Provisions dated November 30,1979

A summary of the meeting highlights follows.

\section{Proceedings}

General

The proceedings of the meeting will be summarized using the following categories:

$$
\begin{aligned}
& \text { Item A - Background Information } \\
& \text { Item B - Work Plan } \\
& \text { Item C - Preliminary Comments on Chapters } 6 \text { and } 7
\end{aligned}
$$

\section{Item A: Background Information}

1) Lawrence Salomone called the meeting to order, presented the agenda for the meeting, summarized some of the milestones in the schedule, informed the members of the source documents which are available (\#andouts 2 and 3 ), circulated the List of Comittee 3 Members for review and comment and answered any questions.

\section{2) Richard Simon was elected Chairman.}

3) Joseph V. Tyrrell was selected to represent Comittee 3 in Committee 2.

4) The next meeting will be held in the offices of Law Engineering Testing Company, 109 Inverness Drive East, Suite West 3, Englewood, Colorado 80110 on February 15,1980 at 9:00 A.X. Arrangements for the 
meeting will be made by James LaBastie.

5) In response to the question raised at the meeting why no BSSC representative has been selected, the writer has learned that an individual will be selected. However, similar to other comittees, circumstances did not permit selection of a BSSC representative before the December 11 , 1979 meeting.

6) Lawrence Salomone informed the members that Chapter 3 of TN1100 (pages 20-29) sumarizes the findings of the study of the ATC - 3 provisions and that Committee 3 may find Section 3.3.5, and Sections 3.1.4, 3.1 .5 and 3.5 helpful.

Item B: Work PIan

1) It was agreed that Chapters 6 and 7 were difficult to read and that not enough background information was provided. It was hoped that the ATC representative will be able to attend the next meeting in order to provide the necessary background information. Richard Simon will call Henry Degenkolb, the ATC representative, to inform him of the time and location of the next meeting.

2) The schedule will require that the equations presented in Chapter 6 be accepted. However, the committee will use the review time available to see if the equations can be used.

3) Richard Simon suggested that the members read some of the other sections in the AIC report (e.g. Chapters 1 and 2 ) before the next meeting to aid in their understanding of the contents of Chapters 6 and 7 .

4) Richard Simon encouraged the committee to solicit comments from their colleagues.

\section{Item C: Preliminary Comments on Chapters 6 and 7}

1) The committee discussed the need for spread footings to be interconnected by ties in Section 7.5.2. William Travis questioned the need and thought that the economic impact of this requirement would be great. $\mathrm{J}$. LaBastie indicated that some conservatism may be necessary considering the different levels of background and experience of the users of a standard. William Travis said the problem is that this section does not allow the designer to demonstrate that ties between spread footings are not necessary. William Travis will call Uenry Degenkolb to ask him why this requirement is in the ATC provisions.

2) Richard Simon pointed out the relative absence of the need to evaluate liquefaction potential of foundation soils in the report. Iiquefaction 
does not seem to be extensively discussed. The comittee agreed that some provision may be necessary. R. Simon will draft a recomendation regarding the evaluation of the liquefaction potential of foundation soils.

3) Joseph Tyrrell said that it may be necessary to add something about site investigations.

4) The committee agreed that reference to the elastic limit in Section 7.2. 2 should be changed.

5) William Travis discussed the need for requiring ties in pole-type structures. It was concluded that it may not be necessary because of the relative importance of the structures covered by Section 7.4.2.

Respectfully submitted,

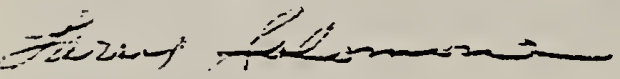

Larry Salomone, Secretary 
Table 1

List of Participants

$\underline{\text { Participant }}$

James G. LaBastie

Richard Simon

Joseph V. Tyrrell

William Travis

Lawrence A. Salomone

(Secretariat)

Riley Chung

Visitor

Felix Y. Yokel

Chairman, ASCE

Committee on Foundation

and Excavation Standards
Organization

American Society of Civil Engineers

Association of Soil and Foundation Engineers

Interagency Committee on Seismic Safety in Construction

Structural Engineers Association of California

National Bureau of Standards

National Bureau of Standards

National Bureau of Standards 
American Society of Civil Engineers

Mr. James G. LaBastie

6252 Powell Road

Parker, Colorado 80134

Phone: $\quad 303-771-8641$

Association of Soil and Foundation Engineers

Mr. Richard Simon

(Chairman)

Goldberg, Zoino, Dunnicliff \& Assoc., Inc.

30 Tower Road

Newt on Upper Falls, Massachusetts 02164

Phone: 617-969-0050

Interagency Committee on Seismic Safety in Construction

Mr. Joseph V. Tyrrell

Director, Civil/Struc. Div.

Naval Facilities Engineering Comnd.

200 Stovall Street

Alexandria, VA 22332

Phone: 202-325-0064

Structural Engineers Association of California

Mr. William Travis

7851 Mission Center Court

Suite 250

San Diego, California 92108

Phone: 714-291-2800

Applied Technology Council

Mr. Henry Degenkolb

H. J. Degenkolb \& Associates

350 Sansome Street

San Francisco, CA 94104

Building Seismic Safety Council 
Committee 3 (continued)

National Bureau of Standards

Mr. Larry Salomone

Secretariat

Committee 3, Foundations

National Bureau of Standards

Rm. B168, Bldg. 226

Washington, D. C. 20234

Phone: $301-921-3128$

(Dr. Riley Chung)

Phone: 301-921-2137

(Dr. Felix Yokel)

Phone: 301-921-2648

301-921-2647 


\author{
Minutes of 2nd Meeting \\ of \\ Technical Committee No. 3 \\ on Foundations \\ for \\ Review and Refinement \\ of Tentative Seismic \\ Provisions (ATC-3-06)
}

at

Law Engineering Testing

Company

February 15, 1980

\title{
Introduction
}

On February 15, 1980, a meeting was held at Law Engineering Testing Company, 109 Inverness Drive East, Englewood, Colorado. This was the second meeting of the group assembled for reviewing and refining Chapter 6, Soil-Structure Interaction, and Chapter 7, Foundation Design Requirements, in the ATC Report (NBS SP-510) entitled "Tentative Provisions for the Development of Seismic Regulations for Buildings." The meeting served as a workshop to discuss comments received by February 15, 1980 on Chapter 6 and 7 and to develop recommendations for revising these chapters. The participants in the meeting are listed in Table 1, List of Participants. A numerical listing of the sections in which comments were received was prepared by Richard Simon, Chairman of Technical Committee No. 3 and provided to the committee members (Table 2). At the beginning of the workshop the secretary of Technical Committee 3, Lawrance Salomone, distributed comments from the Concrete Reinforcing Steel Institute and Professor V. V. Bertero of the University of California, Berkeley. These comments were sent to Committee 4 and were not received by Committee 3 until just prior to the workshop. Joseph V. Tyrrell, representative of Committee 3 in Committee 2, distributed the comments sent to Committee 2.

\section{$\underline{\text { Proceedings }}$}

The workshop was conducted in the following manner:

1) Each of the comments received (Table 2) were discussed and a final position of the committee developed. The final position consisted of a recommendation for change for the Section in question or a recommendation that the Section not be modified.

2) Following development of the final position of the committee a vote was taken. 
The meeting highlights were:

1a Section 3.2.1 Paragraph 4

Author of Comment - Joseph V. Tyrrell, Interagency Committee on Seismic Safety in Construction.

1b Excerpt from ATC 3-06

"In location where the soil properties are not known in sufficient detail to determine the soil profile type or where the profile does not fit any of the three types, Soil Profile $\mathrm{S}_{2}$ should be used."

1c Comment:

Soil Profile Type $\mathrm{S}_{2}$ is much better than Type $\mathrm{S}_{3}$. This section suggests soil profile Type $S_{2}$ when the soil properties are not known. This does not seem logical.

\section{1d Discussion}

The discussion centered around Figure C1-13, Normalized Lateral Design Force Coefficients $\left(A_{a}=A=1.0\right)$ and the effect of soil type on the normalized design coetficient.

le Recommendation

The last paragraph in Section 3.2 .1 should be changed to read "In locations where the soil properties are not known in sufficient detail to determine the soil profile type or where the profile does not fit any of the three types, Soil Profile $\mathrm{S}_{2}$ or Soil Profile $\mathrm{S}_{3}$ shall be used depending on whichever soil profile type results in the higher value of seismic coefficient $C_{3}$, as determined in Section 4.2 .1 .

If Ballot - The recommendation for change was voted on and unanimously accepted by the members of Committee 3.

2 a Section 3.2.1 Paragraph 1 "...stable deposits of sands, gravels or stiff clays."

Author of Comment - Richard M. Simon, Association of Soil and Foundation Engineers

2b Excerpt from ATC 3-06

"Stiff soil conditions where the soil depth is less than 200 feet and the soil types overlying rock are stable deposits of sands, gravels, or stiff clays."

2c Comment

The use of the word "stable" was questioned. 
$2 d$ Discussion - The group discussed the appropriateness of the use of the word "stable". J. LaBastie, American Society of Civil Engineers, stated that he had no problem with the term stable. The committee agreed and no change was recommended.

3a Section 7.1, Paragraph 1

Author of Comment - Joseph V. Tyrrell, Interagency Committee on Seismic Safety in Construction.

3b Excerpt from ATC 3-06

"These include, but are not limited to provisions for the extent of investigation, fills, slope stability, bearing and lateral soil pressures, reports, drainage, settlement control, and pile requirements and capacities."

3c Comment:

The word "reports" here does not read right. Suggest the last sentence be changed to: "... These include ... fills, slope stability, bearing capacity, lateral soil pressure and support, drainage and settlement control, and pile requirement and capacities."

\section{3d Discussion}

The committee referred to the commentary on page 403 of the ATC 3-06 document in which Section 7.1 is discussed. The committee felt that this section is discussed in the commentary and the proposed change would not add anything.

3e Recommendation

J. Tyrrell suggested dropping the comment and the committee agreed to J. Tyrrell's recommendation.

4a Section 7.22, Paragraph 1

Authors of Comments - Joseph V. Tyrrell and Richard M. Simon

4b Excerpt Erom ATC 3-06

"... the soil capacities must be. sufficient to provide resistance at the elastic Iimit or less ...." 
4c Comment (Joseph V. Tyrre11)

This section is not clear as the elastic limit of the soil is generally difficult to define. Furthermore, the soil bearing capacity is developed from the plastic equilibrium concept. Thus, to use the elastic limit to restrain the capacities of the soil resistance is not reasonable. This needs clarification.

Comment (Richard M. Simon)

The last sentence of this paragraph states...Soil capacities must be sufficient to provide resistance at the elastic limit or less considering both the short time of loading and the dynamic properties of the soil." Soils are inherently inelastic materials and to specify stressing below the elastic limit is practically without meaning. The term "elastic limit" should be replaced with a term such as peak shear strength, yield limit, or other which has a more significant meaning for soils. Because elastic has so little meaning for soils, it is not possible to know what the author of this section had in mind when writing this sentence.

\section{4d Discussion}

The committee discussed the fact that "elastic limit" was not the correct term to use and discussed alternate terminology for elastic limit.

\section{4 e Recommendation}

The last sentence in Section 7.2.2 should read "For the load combination including earthquake as specified in Sec. 3.7, the soil capacities must be sufficient to resist loads at acceptable strains considering both the short time of loading and the dynamic properties of the soil.

\section{$4 \mathrm{f}$ Ballot}

The recommendation for change was voted on and unanimously accepted by the members of Committee 3 .

\section{5a Section 7.4 .2}

Author of Comment - Wm. Travis, Structural Engineers Association of California.

5b Excerpt from ATC 3-06

Construction employing posts or poles as columns embedded in earth or embedded in concrete footings in the earth may be used to resist both axial and lateral loads. The depth of embedment required for posts or poles to resist seismic loads shall be determined by means of the design criteria established in the foundation investigation report. 
5c Comment

No formal comment was proposed.

\section{5d Discussion}

William Travis discussed the need for requiring ties in pole-type structures. Henry Degenkolb mentioned that in San Francisco ties are required in Class $C$ and $D$ structures. However, it was also stated that pole-type structures were used only for agriculture purposes.

Se Recommendation

William Travis suggested dropping the comment and the committee agreed to his recommendation.

6a Section 7.4.3, Paragraph 1

Author of Comment Richard M. Simon

6b Excerpt from ATC 3-06

Individual pile caps, drilled piers, or caissons shall be interconnected by ties. All ties shall be capable of carrying, in tension or compression, a force equal to $\mathrm{A} / 4$ of the larger pile cap or column load unless it can be demonstrated equivalent restraint can be provided by other approved means.

6c Comment

In my opinion, it is overly conservative to require structural ties between pile caps equal to $25 \%$ of the maximum vertical load for a Category B structure. This conservatism is amplified in the commentary of this paragraph where it states, "Lateral soil pressure on pile caps is not a recommended method; and if the soil is soft enough to require ties, little reliance can be placed on soft-soil passive pressure to restrain relative displacement under dynamic conditions." There are many cases in which the use of piles is dictated by deep soil deposits and the near surface materials are relatively stiff and strong (such as compact or dense gravels and sands overlying soft clays or controlled, compacted fill over clays or organic soils. In these cases, it would seem reasonable to permit at least a portion of the lateral tie resistance between the pile caps to be provided by lateral soil resistance with some guidance provided. In light of these considerations, the following changes in the tentative provisions and commentary are suggested:

a) Section $7.4 .3--$ Sentence 2

$A_{v} / 4$ should be changed to $A_{v} / 6$. 
b) Section 7.5 .2

"Individual pile caps, drilled piers, caissons or spread footings shall be interconnected by ties. All ties shall be capable of carrying by tension or compression $A / 4$ of the larger footing or column load unless it can be demonstrated that equivalent restraint can be provided by other approved means."

c) Commentary -- Section 7.4.3 Paragraph 3

In my opinion it is overly conservative to preclude the use of lateral soil pressure on pile caps and spread footings from consideration in tying of foundation elements in all cases. The alternative paragraph below is a suggested replacement for the paragraph provided in the Commentary:

1. Alternative methods of tying foundation together are permitted, such as use of properly reinforced floor slab that can take both tension and compression. Lateral soil pressure on pile caps is not a recommended method if the pile caps are embedded in soft soil because the motion is transmitted from soil to structure (not inversely, as is commonly assumed); if the soil is soft enough to require ties, little reliance can be placed on soft-soil passive pressure to restrain relative displacement under dynamic conditions. However, if pile caps or caissons are embedded in stiff soil such as medium dense to dense sand or sand and gravel or stiff to hard clay, and backfill surrounding the pile caps or caissons is systematically compacted to a minimum of $95 \%$ of the modified Procter density, lateral soil pressure may be used to provide $100 \%$ of the required lateral force for category $B$ structures. No contribution to the lateral force on the pile cap may be provided by shear stresses on the base of the pile cap because underlying soils may settle the soil from beneath this pile cap leaving a gap. For category $C$ or $D$ structures, lateral soil pressure may be used to provide up to $50 \%$ of the lateral force required for foundation ties. For category $C$ or $D$ structures on spread footings, the laceral forces may be used to provide up to $50 \%$ of the total required tie force and both lateral pressure on sides of footings as well as shear stresses on the base of footings may be considered to provide the necessary force.

\section{6d Discussion}

Richard Simon said that one should be able to take advantage of the compacted backfill. William Travis said that piles should be tied together. The committee discussed using the term "rock" in Section 7.4 .3 (material with a shear wave velocity of 2500 fps).

$\underline{\text { Recommendation }}$

The committee decided not to modify Section 7.4.3. 
7a Section 7.5.2, Paragraph 1

Author of Comment Richard M. Simon

7b Excerpt from ATC 3-06

Individual spread footings shall be interconnected by ties. All ties shall be capable of carrying, in tension or compression, a force equal to $\mathrm{A} / 4$ of the larger footing or colum load unless it can be demonstrated that equivalent restraint can be provided by other means.

7c Comment

See Item $6 c$.

7d Discussion

The committee discussed terminology that would be appropriate.

7e Recommendation

The first sentence in Section 7.5 .2 should be changed to read "Individual spread footings unless founded directly on rock, as defined in Section 3.2.1 (1), shall be interconnected by ties."

$7 \mathrm{f} \quad \underline{B a 110 t}$

The recommendation for change was voted on and unanimously accepted by the members of Committee 3 .

8a Section 7.4.4, Item A, Uncased Concrete Piles

Author of Comment Joseph V. Tyrrell

8b Excerpt from ATC 3-06

\section{(A) UNCASED CONCRETE PILES}

Reinforcing steel shall be provided in the top portion of uncased cast-in-place concrete piles or caissons for a distance of ten pile diameters, with a minimum steel ratio of 0.0025 with a minimum of four No. 5 bars. Ties (or equivalent spirals) shall be provided at 16-bar diameter spacing (maximum spacing) with a maximum spacing of 4 inches in the top 2 feet.

8c Comment

The pile diameters generally range from 12 inch to 16 inch, but caisson shaft diameters are generally 24 inch to 30 inch minimum. The ten pile diameter reinforcement requirement for caisson would 
be excessive. I believe the word "kaisson" here means drilled piers or drilled caissons.

\section{8d Discussion}

J. Tyrrell thought a minimum steel ratio of .0025 was too high. The committee then discussed the need for steel and the amount of steel required in caissons. J. LaBastie said he never saw caissons without steel. William Travis pointed out that steel may be needed since stresses due to concrete shrinkage and tests have shown the steel is necessary. J. Tyrrell concluded the discussion by saying that he did not have strong feelings about his comment.

8 e Recommendation

The committee decided not to modify Section 7.4.4, Item A.

9a Section 7.4.4, Item E, Paragraph 1

Author of Comment - David A. Sheppard, Prestressed Concrete Institute

$9 b$ Excerpt from ATC 3-06

(E) PRECAST-PRESTRESSED PILES.

The upper 2 feet of the pile shall have No. 3 ties minimum at not over 4-inch spacing, or equivalent spirals. The pile cap connection may be by means of dowels as required in Sec. 7.4.4(C).

9c Comment

Revise Section 7.4.4(E) to read as follows: The upper 2 feet. . - or equivalent spirals. The pile cap connection may be made by developing exposed strand or by the use of field placed anchor dowels grouted into sleeves cast in the pile top as outlined in Section 11.9 .

BASIS: Present accepted practice in UBC-79 and CAL-TRANS specifications

\section{9d Discussion}

H. Degenkolb showed pictures of how piles shattered at the top during the 1971 San Fernando Earthquake. Precast prestressed piles performed poorly.

The committee discussed possible designs for the connection at the top of the pile. It was agreed that the intent was to put the ductile section where the hinge would form. Considering this fact and the comment from David Sheppard, PCI, a recommendation for changes was prepared. When addressing Sheppard's comment the committee did not accept the use of an exposed strand. 
At the end of paragraph 2 of Section 7.4 .4 (before Item A) the following sentence should be added, "Where special reinforcement at the top of the pile is required alternative measures for containing concrete and maintaining ductility will be permitted provided due consideration is given to forcing the hinge to occur in the contained section."

\section{$9 \mathrm{f} \quad$ Ballot}

The committee unanimously rejected the comment made by the Prestressed Concrete Institute. The recommendation for change was voted on and unanimously accepted by the members of Committee 3.

10a Section 7.5.3 (C) Paragraph 1

Authors of Comments - David A. Sheppard, PCI and Joseph G. Manning, Concrete Reinforcing Steel Institute

$10 \mathrm{~b}$ Excerpt from ATC 3-06

\section{(C) PRECAST CONCRETE PILES.}

Ties in precast concrete piles shall conform to the requirements of Sec. 11.6.2 for the top half of the pile. Precast concrete piles shall not be used to resist flexure caused by earthquake motions unless it can be shown that they will be stressed to below the elastic limit under the maximum soil deformations that would occur during an earthquake.

10c Comment (D. Sheppard, PCI)

Revise the last sentence of Section 7.5.3(c) to read as follows: "Precast concrete and prestressed concrete piling shall be designed to withstand maximum imposed curvatures resulting from a dynamic analysis of the soil profile present, with detailing as specified in Section 11.9."

BASIS: See my letter and accompanying documentation from Gerwick, et al presented at the BSSC meeting on November 8, 1979.

Comment (Joseph G. Manning, CRSI)

Revise second sentence to read as follows:

Precast concrete and prestressed precast concrete piling shall be designed to withstand maximum imposed curvatures resulting from the maximum soil deformations that would occur during an earthquake.

Reason: Prestressed precast concrete piling can withstand considerable curvature and through proper detailing confinement and ductility can be provided. 


\section{0d Discussion}

The committee discussed the validity of D. Sheppard's comment and agreed that it should be accepted. The committee also considered the comment from Joseph G. Manning, Concrete Reinforcing Steel Institute, and decided the comment was similar to

D. Sheppard's comment.

\section{0 e Recommendation}

The last sentence in Section 7.5.3(c) should be revised to read, "Precast concrete and prestressed concrete piling shall be designed to withstand maximum imposed curvatures resulting from a dynamic analysis of the soil profile.

\section{$10 \mathrm{Ballot}$}

The recommendation for change was voted on and unanimously accepted by the members of Committee 3 .

lla Section 7.6.1, Paragraph 1

Authors of Comments - David A. Sheppard, PCI, and Joseph G. Manning, CRSI

\section{$11 b$ Excerpt from ATC 3-06}

Sec. 7.6.1 SPECIAL PILE LIMITATIONS

Precast-prestressed piles shall not be used to resist flexure caused by earthquake motions.

11c Comment (David A. Sheppard)

Sec. 7.6 .1

Revise this section to read as follows: "All piling types in Category $D$ shall be designed to withstand maximum imposed curvatures resulting from a dynamic response analysis of the soil profile present."

BASIS: Same as 7.5 .3 above. Foundation requirements should be performance oriented, and not arbitrarily penalize certain materials (prestressed concrete) because of local bias, in spite of recent tests and successful design applications developing large curvatures resulting from layered soil movements in maximum credible seismic conditions.

Comment (Joseph G. Manning)

Section 7.6 .1 Special Pile Limitations

Delete this section.

Reason: See comments on Section 7.5.3. 
The committee considered the comments that were received, but decided that additional conservatism was required for Category $D$ structures. Therefore, Section 7.6.1 should not be modified.

\section{Ile Recommendation}

The committee recommended not to change or delete Section 7.6 .1

\section{2 a Chapter 6}

Author of Comment - Richard M. Simon and William M. Travis

12b Excerpt from ATC 3-06

Refer to pages $65-71$ in ATC 3-06 report.

12c Comment (Richard M. Simon)

1. Chapter 6 --SOIL-STRUCTURE INTERACTION

Chapter 6 contains some relatively complex equations for adjustment of the equivalent lateral force and modal analysis procedures for evaluation of earthquake induced forces. It may be inappropriate to include these soil structure interaction (SSI) equations in the tentative provisions document at this time for the following reasons:

a) Both the equivalent lateral force and modal analysis procedures are approximate in themselves. There have been few prototype observations to explore the accuracy of either procedure. The equations contained in Chapter 6 are based solely on analytical studies with almost no prototype or even laboratory verification. Because of the approximate nature of the entire analysis procedures it is, in my opinion, inappropriate to add an additional level of sophistication to the equations. The SSI equations are so complex as to make me question whether they could be properly applied by the average structural/civil engineer. There are no guidelines provided in the provisions or commentary as to the approximate magnitude of the effect produced by these equations other than the reduced base shear shall in no case be taken less than 0.7 times the rigid support base shear. Little guidance is provided in the readily available published literature. Although failure to incorporate the effects of SSI is in almost all cases a conservative assumption, it is not clear that applying the equations without complete understanding and with potential errors will lead to conservative design forces and displacements. 
b) The Tentative Provisions have emphasized the inelastic behavior of structures in response to earthquake loading. The analytical procedures used as the basis of the Ghapter 6 provisions assume a linear response for the superstructure which is inconsistent with the general philosophy of the Tentative Provisions.

c) It may be inconsistent with the charges of this committee to expurgate the entire chapter of the provisions at this review stage, however, as a minimum, it is recommended that the trial designs be carried through both with and without use of the SSI equations so that an evaluation of the effect of these equations on the final design may be determined. If the effect of the SSI equations is shown by trial designs to be of little significance, it may be proper to omit the entire section at that time.

\section{Section $6.1-$ - General}

Inasmuch as the SSI equations require the expenditures significant additional design effort with questionable return in terms of design savings, Section 6.1 does not contain a clear enough statement that they may be conservatively ignored. To clarify this idea, it is recommended that the following sentence be impended to the end of paragraph 1 of the section: It is acceptable to evaluate the design earthquake forces and corresponding displacement of the building using only the equations contained in chapters 4 and 5 .

Comment (William L. Travis)

See letter from William L. Travis to Lawrence A. Salomone dated $2 / 20 / 80$ (attached).

\section{2d Discussion}

R. Simon opened the discussion by outlining three approaches with respect to Chapter 6 :

1) Do not change Chapter 6

2) Omit Chapter 6

3) Do trial designs both ways

In addition, H. Degenkolb presented the background on Chapter 6 . He said the section is theoretical.

Simon then said that this section lowers coefficient and hardware to resist earthquakes. William Travis followed by presenting the need for having a practical feel for what the structure is doing. He showed the complexity of the procedure in Section 6.0 (see Travis's letter dated February 20, 1980). The theoretical approach results in losing sight of what actually is happening. William Travis 
said he thought Chapter 6 should be cleaned up and it should be modeled after UBC. He thought that an error could be made using Chapter 6 and the designer would not know it. Chapter 6 is too complicated for the practicing engineer and it is not justified.

J. Tyrrell said his people ran through the Chapter 6 procedure and he supported William Travis's comments. It was pointed out that John Christian of Stone \& Webster said that the procedure was sound. However, William Travis said he did not agree. J. La Bastie explained that John Christian's experience is mainly in soils and nuclear power plants.

After these comments were expressed the committee discussed what course of action could be taken. It was pointed out that in the beginning of the ATC 3-06 report it was said that Chapter 6 could be ignored (it stands alone). Therefore, the impact of eliminating or modifying Chapter 6 would be minimal. Furthermore, page 4 of the guidelines given to committee members states that the effectiveness of a section can be questioned. The committee felt that soil conditions were considered by $S$ factors. Consequently, they formulated and agreed to the position stated below.

\section{$12 \mathrm{e}$ Recommendation}

After reviewing Chapter 6 and thoroughly examining the procedures therein, the committee feels strongly that the provisions are not effective in implementing a new concept. Chapter 6 is too complicated for the practicing engineer and it is not justified based on field observations. The sophistication of the analysis is inconsistent with the accuracy of the results and the complexity masks the understanding of the performance of the soil structure system. Consequently, the committee recommends deleting Chapter 6 from the tentative provisions.

With the completion of the discussion of Chapter 6 the meeting was adjourned. It was agreed that:

1) A draft of the minutes will be distributed for review and comment by the committee members.

2) William Travis will send the required backup for elimination of Chapter 6 within 3 weeks of the date of the meeting.

3) Committee members will send letters documenting their vote regarding the items discussed. (Please use the enclosed form for this documentation).

4) There is no need to send out a ballot for the items discussed except for Chapter 6 .

5) Any future discussions that were required would be performed by a telephone conference call. 
TABLE 1

Meeting $2 / 15 / 80$

List of Attendees

$\underline{\text { Participant }}$

Lawrence Salomone

William L. Travis

Henry J. Degenkolb

J. G. LaBastie

J. V. Tyrrell (IACSSC)

Richard M. Simon $\underline{\text { Affiliation }}$

NBS

SEAOC

ATC 3-06

ASCE

Naval Fac., Eng. Com.

ASFE 
TABLE 2

\author{
Numerical List of Sections \\ Prepared by Richard Simon \\ Prior to February 15, 1980 Meeting
}

a. Default $\mathrm{S}_{2}$

Tyrre11

b. "Stable" deposits

Simon of $S \& G$

Simon

b. Omit

c. Trial designs both ways

"reports"

Tyrrel1

4

$\S 7.2 .2$

"elastic limit"

Tyrre11, Simon

$\S 7.4 .2$

Pole structures

Travis

6

§ 7.4 .3

Foundation ties

Simon

§ 7.44

Exposed strand

PCI

8

$\S 7.53$

"withstand curvature"

PCI

elastic limit

PCC piles 
REVIEW AND REFINEMENT

OF TENTATIVE SEISMIC PROVISIONS (ATC 3-06)

COMMITEE 3 BALLOT

$\mathrm{Pg} 1$ of 2

Committee 3 on Foundations

Issue Date $3 / 10 / 80$

Deadline for Receipt $4 / 1 / 80$

Information and Instructions

1. The return of this ballot is required from voting members of Committee 3 .

2. When voting affirmative with reservations (Column 4) or negative (Column 3) the member can provide an explanation in the remarks colum (Colum 5).

3. The member should refer to the minutes for the February 15, 1980 meeting for a detailed description of the item listed in Column 1.

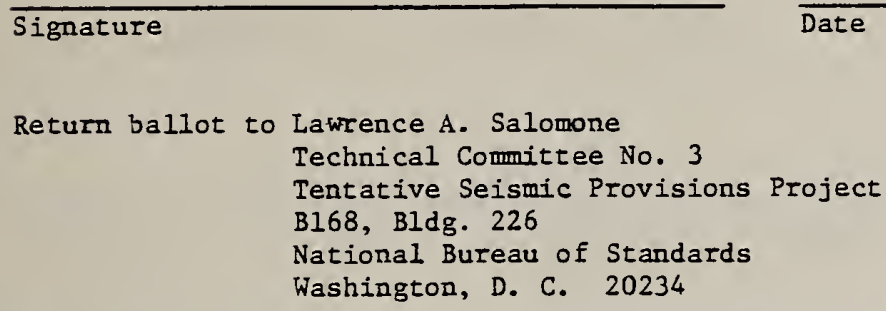

\begin{tabular}{|c|c|c|c|c|}
\hline $\begin{array}{l}\text { Section No. - Item No. } \\
\text { (see minutes from } \\
2 / 15 / 80 \text { mtg.) }\end{array}$ & Affirmative & Negative & $\begin{array}{l}\text { Affirmative } \\
\text { with } \\
\text { Reservations }\end{array}$ & $\begin{array}{l}\text { Remarks } \\
\text { (Check box and } \\
\text { use } \mathrm{Pg} \mathrm{2} \text { ) }\end{array}$ \\
\hline Section 3.2.1 - Item le & & & & \\
\hline Section 3.2 .1 - Item $2 \mathrm{~d}$ & & & & \\
\hline Section 7.1 - Item $3 e$ & & & & \\
\hline Section 7.2 .2 - Item $4 \mathrm{e}$ & & & & \\
\hline Section 7.4 .2 - Item $5 e$ & & & & \\
\hline Section 7.4 .3 - Item $6 \mathrm{e}$ & & & & \\
\hline Section 7.5 .2 - Item $7 e$ & & & & \\
\hline Section $7.4 .4(A)$ - Item $8 e$ & & & & \\
\hline Section $7.4 .4(E)$ - Item $9 e$ & : & & & \\
\hline Section $7.5 .3(\mathrm{C})$ - Item $10 \mathrm{e}$ & & & & \\
\hline Section 7.6 .1 - Item $11 e$ & & & & \\
\hline Chapter 6 - Item $12 \mathrm{e}$ & & & & \\
\hline
\end{tabular}


Review and Refinement

of Tentative Seismic Provisions (ATC 3-06)

Committee 3 Ballot

Pg 2 of 2

Section No. - Item No.

$\underline{\text { Remarks }}$ 


\section{TRAVIS, VERDUGO \& ASSOCIATES}

February 20, 1980

Mr. Lawrence A. Salomone

Secretary Committee 3

National Bureau of Standards

Room Bl68, Bldg. 226

Washington, D.C. 20234

Subject: Comments on Chapter 6, ATC-3

Dear Larry:

As agreed, I have put together some background material for our position as formulated in Denver, February 15, 1980.

Hopefully this will reach you soon enough to distribute with the minutes. Let me know if I can do anything else at this time.

Very truly yours,

TRAVIS, VERDUGO \& ASSOCIATES

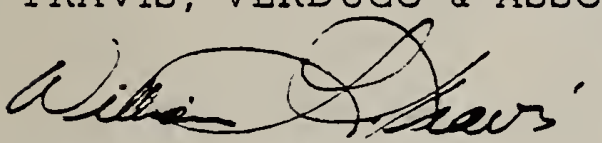

William L. Travis

President

WLT : cdp

Enclosures 
A. While trying to find out how a young practicing engineer might apply Chapter 6. I tried to analyse the steps he would go through. By the 32nd step I was so confused that I forgot what I was trying to find out! Also gone was any feel that I might have had for the effect of the various formulae. (Refer to handwritten notes.)

B. A comparision seemed in order to the relatively simple UBC Chapter 23. The same material is adequately covered on what amounts to less than 4 pages (copies of pages 132-136 from 1976 UBC).

C. A recent publication by Mr. Roy Becker refers to work by Mr. Edward Teal who, while noting that the formula for building period, $T=0.10 \mathrm{~N}$ is inadequate for buildings less than say 40 stories in height and that the Rayleigh Formula should be used suggests that the Rayleigh Formula is impractical to use. Instead, he proposes a simplified version and notes that the SEAOC recommends only two-thirds of the completely arbitrary $0.5 \%$ drift limitation for initial building period calculations. A few of these pages are attached. Note that after these simplifications and approximations with assumed S-values and so on, the SEAOC recommends a further limitation of $\mathrm{T}$.

D. As stated by Mr. Richard Simon, Chairman of the technical committee, the "additional level of sophistication" added to the equations is inappropriate when considering the approximate nature of the entire analysis procedure, at least at this time. Those portions of his comments are attached, with an "AíEN" from Mir. Henry Degenkolb. 
(26) $E=4 \pi \frac{2 \sqrt{X}}{9 T}=0.66$

(27) W defisel' $p \cdot 65$ as $0.7 \mathrm{~W}$ excett...

(10) with $g=$ accel of gravity \& $T$ from above solve for $\bar{k}$

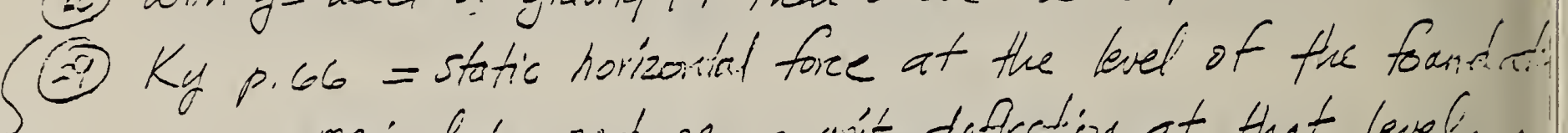
requined to pisctuce a unit diffection at that level...

(3) $K_{\theta}=$ the rocking stifiness of the foundation,... the static momisu. mincessary to produce a unit average rotation of the fouidat ... ??

(3) Cominiany p.396 i395?

iz $\}$

40 


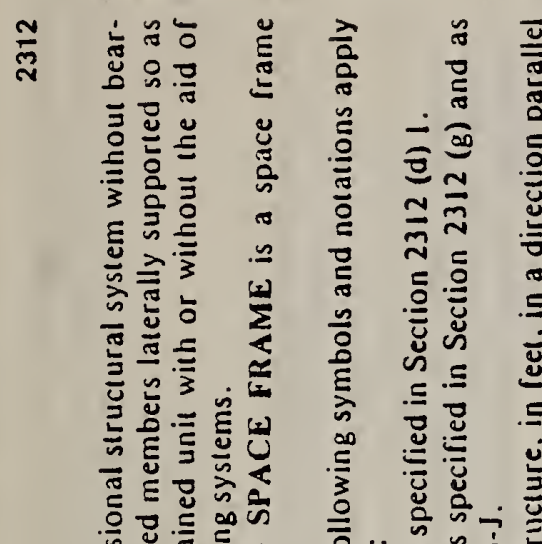

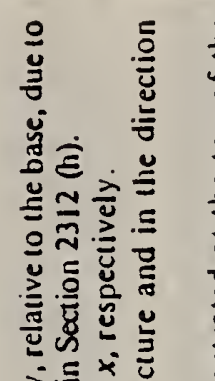

ㅎํำ

ํㅝㄹ

逢气

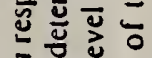

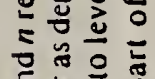

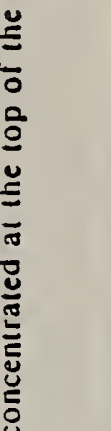

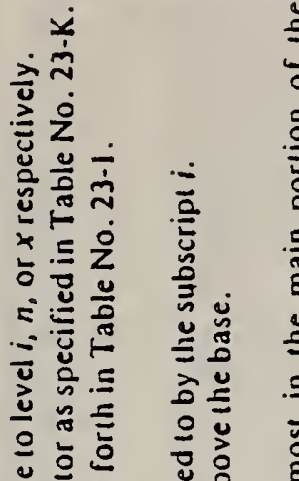

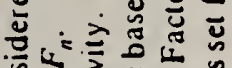

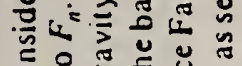

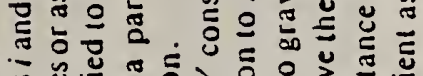

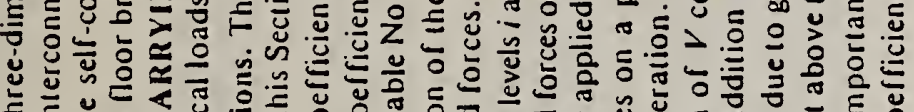

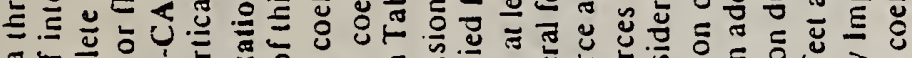

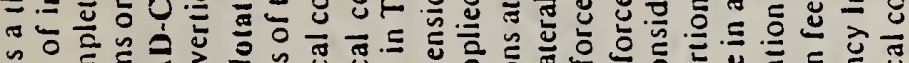

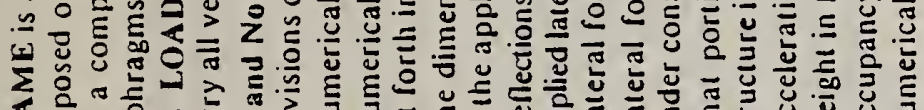

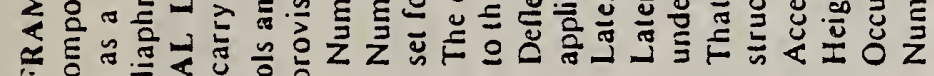

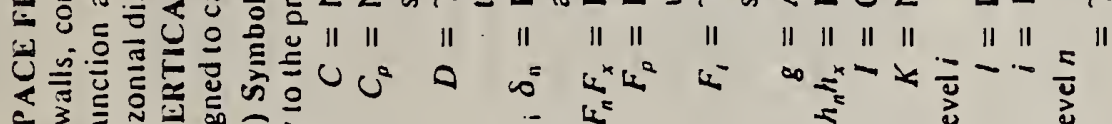

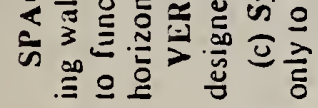

气 气 $\infty k^{2}$

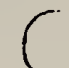

造这 产

ज约

产言

造产要

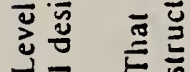

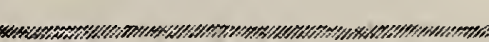

气市 $\overline{\bar{\sigma}}$

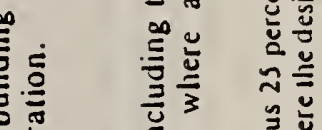

运

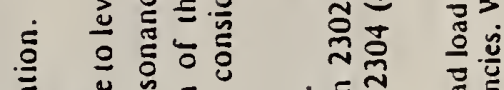

조 흔

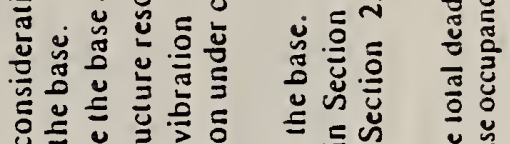

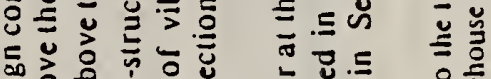

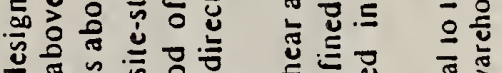

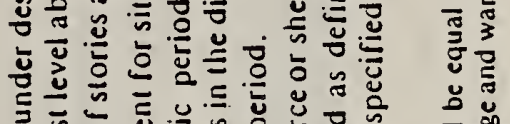

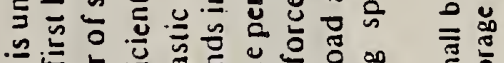

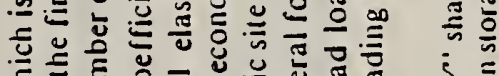

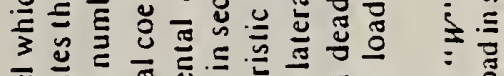

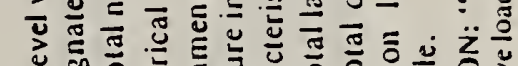

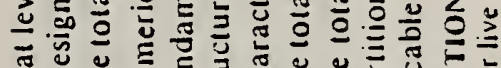

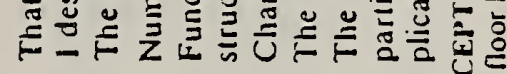
|| || || || || || || || ذँ

$x \geq \sin \quad N^{n} \geq$ 흥

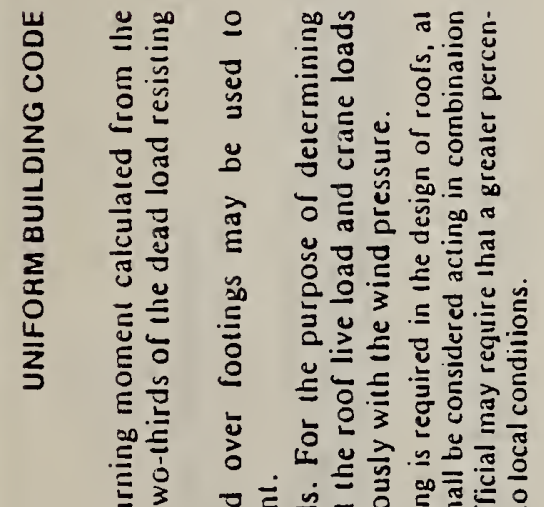

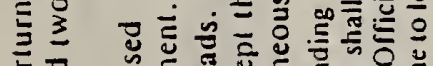

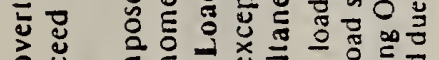

วั

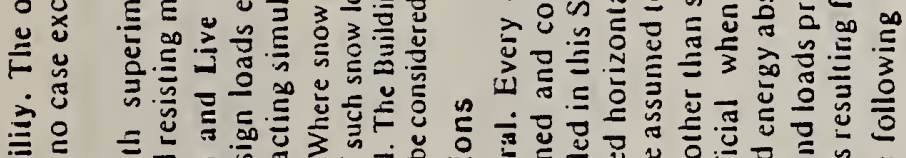

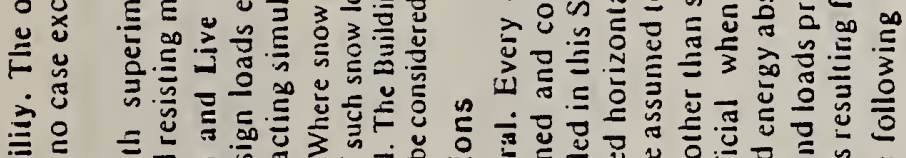

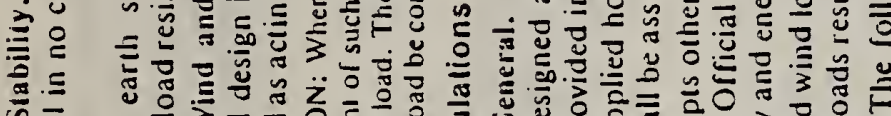

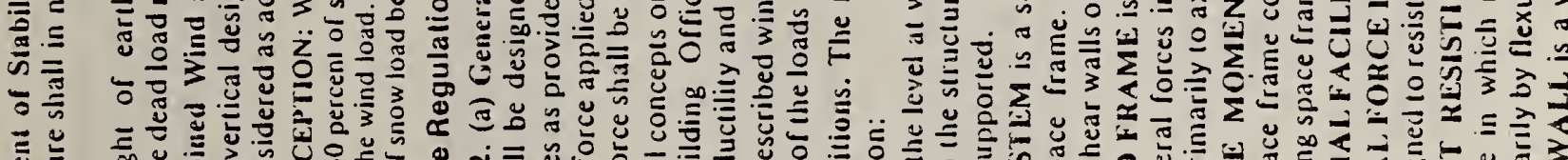

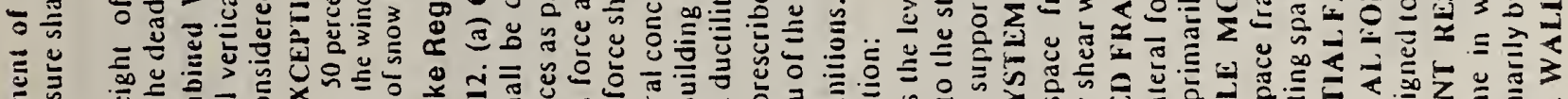

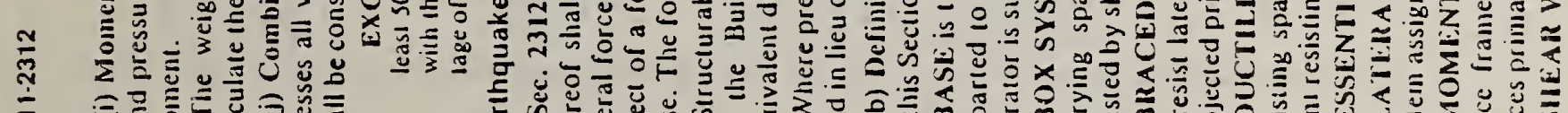
$\overline{\bar{z}}$
ق

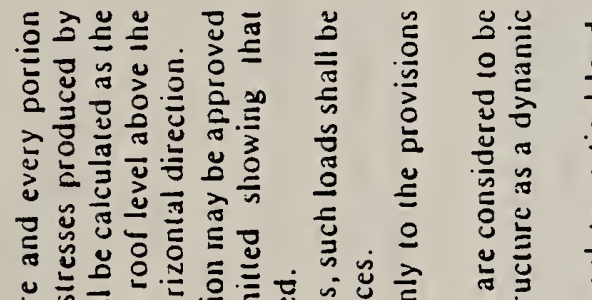

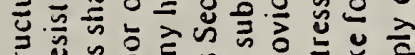

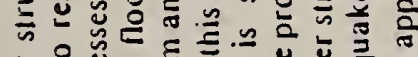

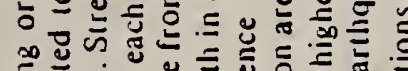

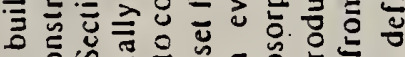

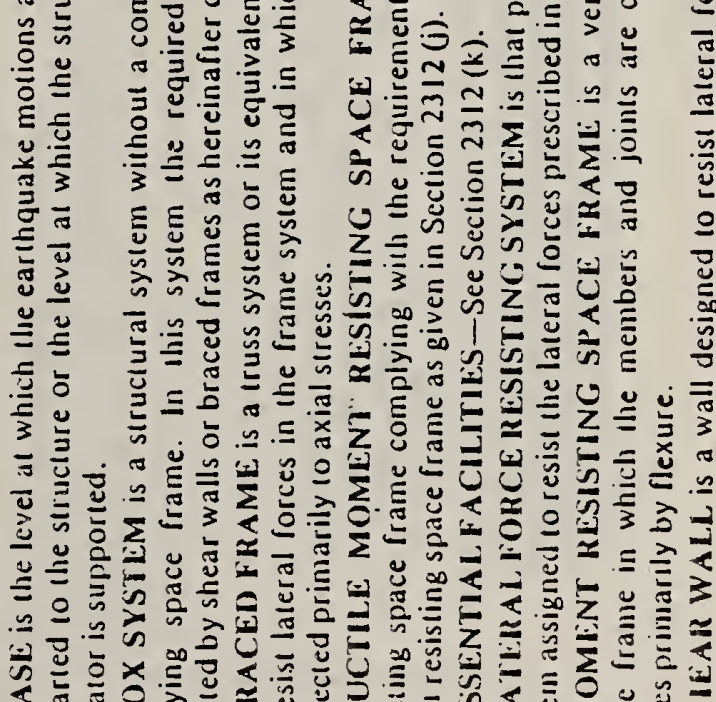

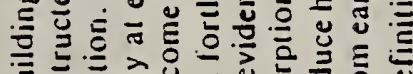

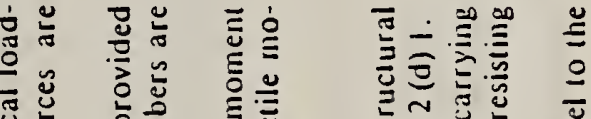

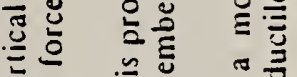

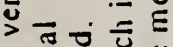
돈

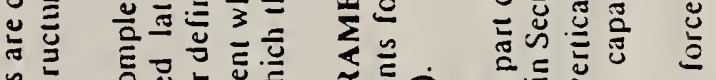

$\therefore$

幽

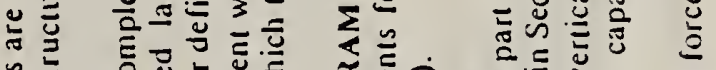

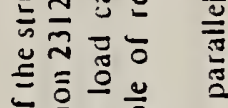

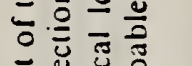

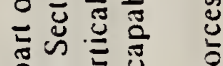

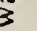




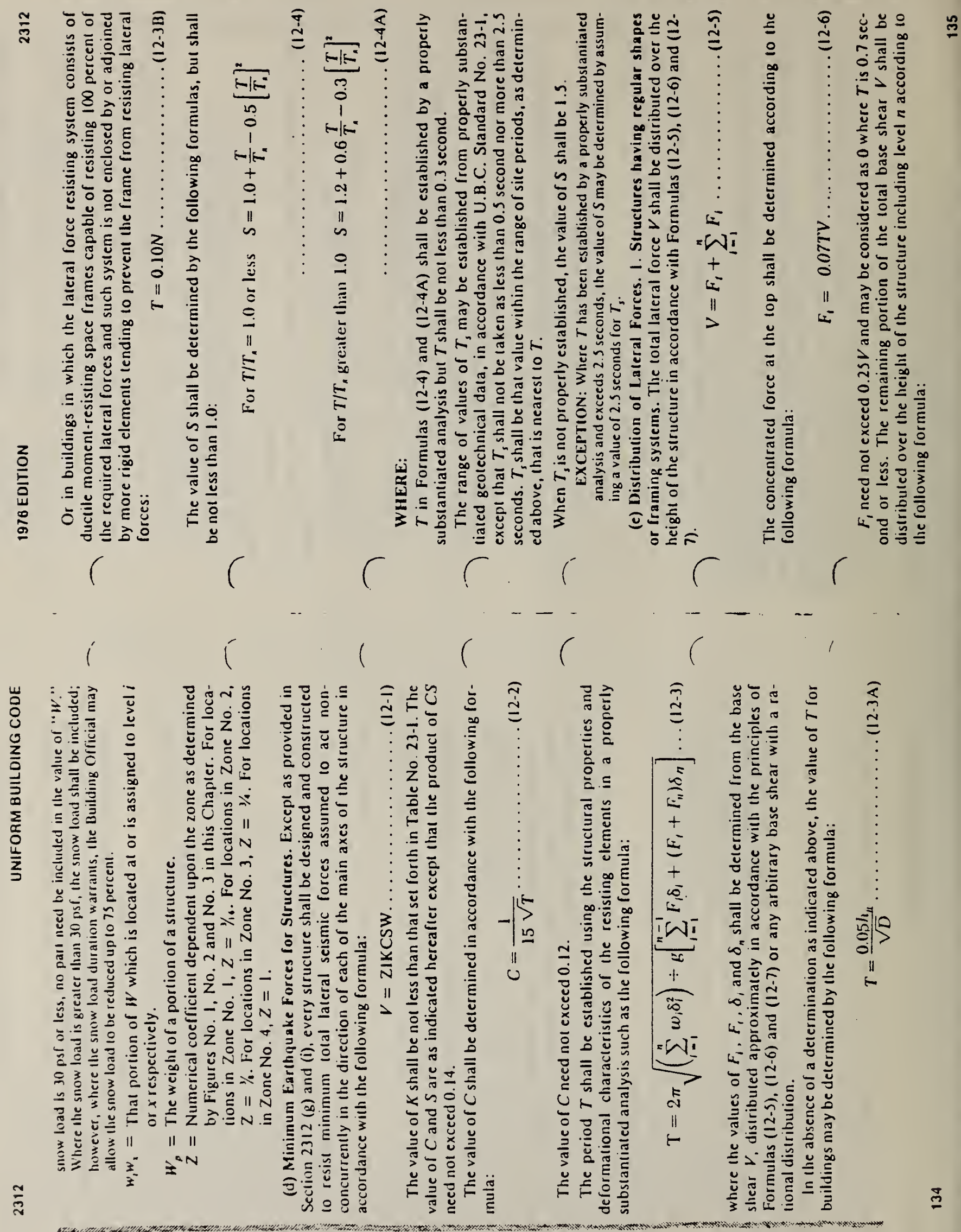




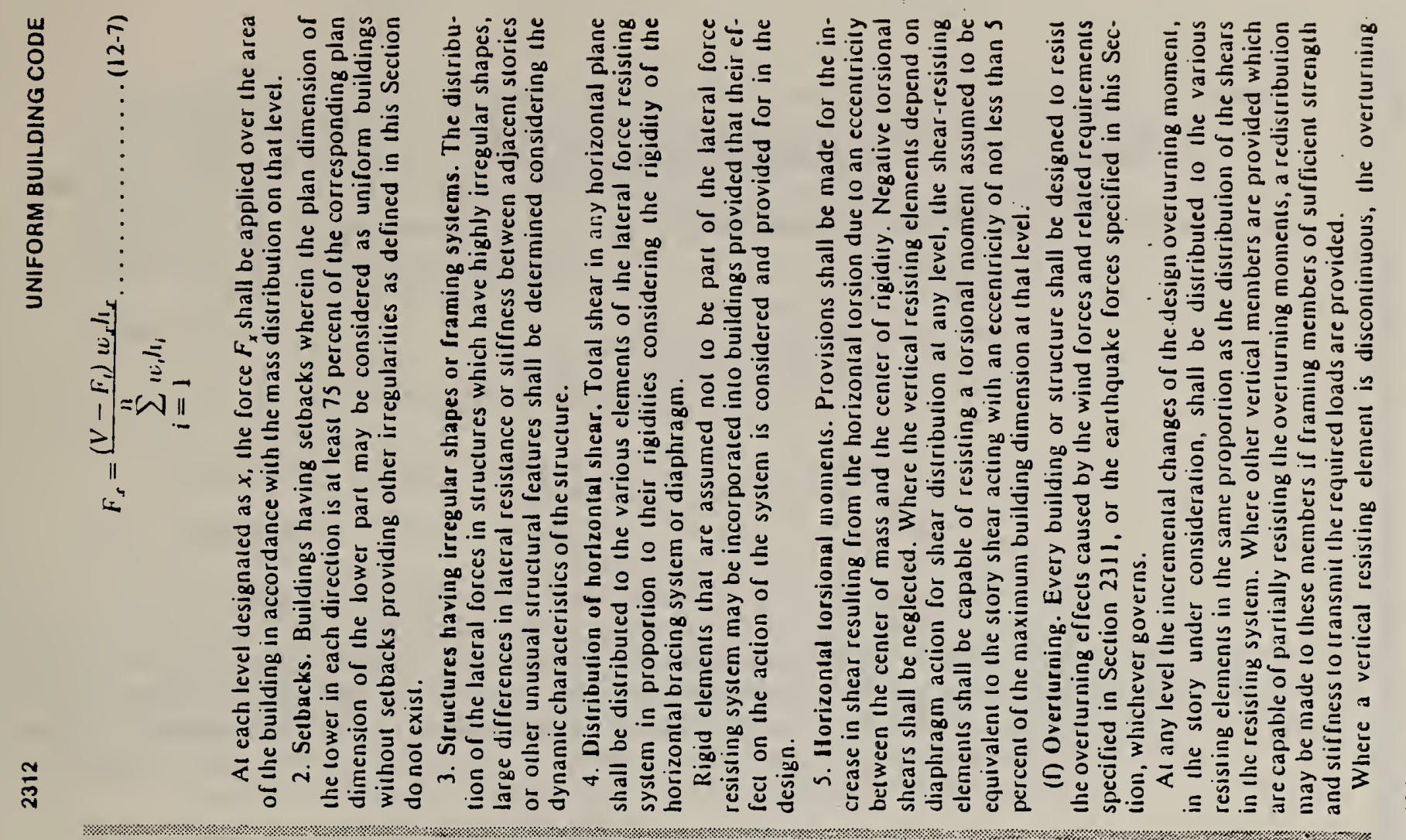


SECTION II: DUCTILE MOMENT FRAME DESIGN*

\section{A.) EAST-WEST SEISMIC FORCES:}

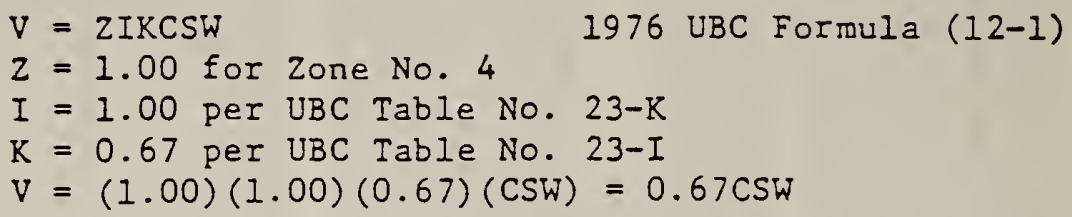

In order to determine $C$, the period $T$ may be taken as:

$$
T=0.10 \mathrm{~N}=0.10(7)=0.70 \mathrm{sec}
$$

however, use of this formula often results in a poor estimate of the period for a moment-resisting frame building. As stated by Mr. Edward Teal in the AISC Engineering Journal, Fourth Quarter, 1975, "this formula yields reasonable period estimates for buildings in the 40story range, but very poor estimates for short buildings." Therefore, Formula (12-3), sometimes known as Rayleigh 's Formula, should be used rather than Formula (12-3B) for determining the period.

$$
T=2 \pi \sqrt{\left(\sum_{i=1}^{n} w_{i} \delta_{i}^{2}\right) \div g\left[\sum_{i=1}^{n-1} F_{i} \delta_{i}+\left(F_{i}+F_{n}\right) \delta_{n}\right]}
$$

For an initial approximation of the building period, Formula (12-3) is impractical to use. However, there is a convenient formula which can br utilized for a good initial approximation without having to do any tria: and error design. It is known as Teal's Method or Formula which is givi by Edward Teal in the AISC Engineering Journals, Second and Fourth Quart, 1975. This formula very closely approximates the actual building perior and is really a simplified version of Formula (12-3):

$V \quad T=0.25 \sqrt{\Delta / C_{1}}$

where

$T=$ Period of building, sec.

$\Delta=$ Lateral deflection at top of building, in.

$C_{1}=$ Lateral force coefficient by which the total weight of the building is multiplied in order to obtain the seismic lateral force due to the building's response to a given base motion.

Drift limitations usually control the design of a moment frame and UBC Sect. $2312(h)$ limits the drift to $0.5 \%$.

* In lieu of a ductile moment frame, this building could utilize a momen frame not meeting the special ductility requirements. See Section III for design of this type of framing system, especially Section III A, "Comparison of Moment Frame with Ductile Moment Frame." 
The SEAOC Commentary recommends that for an initial approximation for this building period, that two-thirds of the allowable drift be used. This factor of two-thirds is used to account for the fact that the maximum drift limits are seldom met over the building's height. (In general, this recommended factor of two-thirds is too small for a steel moment frame unless wind loading criteria governs the design.)

Therefore,

$\rightarrow \Delta=(0.67)(.005) \mathrm{H}=(0.67)(.005)(83.0 \times 12)=3.34 \mathrm{in}$.

Use $\Delta=3.4$ in.

As related to the UBC:

$$
C_{1}=\operatorname{ZICS}=(1.0)(1.0)(C S)=C S
$$

Note that the factor $K$ is omitted from the above equation, since it is a factor assigned to a type of construction in recognition of its inherent resistance to earthquakes and, therefore, is not directly related to stiffness and drift.

\section{Substituting, $\quad T=0.25 \sqrt{3.4 / C S}$}

Since both $C$ and $S$ are rather complex functions of $T$, the solution to this equation might be by trial and error. However, a more direct solution can be achieved by assuming a value for $S$, which has a rather narrow range of values: $1.0 \leq S \leq 1.5$. Assume $S=1.30$.

$$
\begin{aligned}
C & =\frac{1}{15 \sqrt{\mathrm{T}}} \\
C_{1} & =C S=\left(\frac{1}{15 \sqrt{\mathrm{T}}}\right)(1.30)
\end{aligned}
$$

Substituting into Teal's formula,

$$
T=0.25 \sqrt{\frac{3.4}{\left(\frac{1}{15 \sqrt{T}}\right)(1.30)}}=0.25 \sqrt{(3.4)\left(\frac{15}{1.3}\right) \mathrm{T}^{1 / 2}}=1.57 \mathrm{~T}^{1 / 4}
$$

$T^{3 / 4}=1.57 ; T=(1.57)^{1.33}=1.82 \mathrm{sec}$. 
Checking the assumed value of $\mathrm{S}$ :

$$
\begin{aligned}
\frac{T}{T_{S}} & =\frac{1.82}{1.00}=1.82>1.0 \\
S & =1.2+0.6\left(\frac{T}{T_{S}}\right)-0.3\left(\frac{T}{T_{S}}\right)^{2} \quad(12-4 A) \\
& =1.2+0.6(1.82)-0.3(1.82)^{2}=1.30=\text { assumed } S
\end{aligned}
$$

Therefore, $T=1.82 \mathrm{sec}$. is valid.

However, as stated in the SEAOC Commentary, "the Committee feels that the period determination of frame structures should be thoroughly examined if a final period greater than $\mathrm{T}=0.5^{\circ} \mathrm{N}^{2 / 3}$ is calculated." "Thoroughly

examined" probably implies that the following be taken into account: P-s effects, participation of non-moment frames, composite action between girders and floor slab, etc. In order to avoid taking these difficult to determine items into account, the period of the building will be limited by this recomendation.

$$
\begin{aligned}
T & =0.5 \mathrm{~N}^{2 / 3} \\
& =(0.5)(7.0)^{2 / 3}=1.83 \mathrm{sec} .
\end{aligned}
$$

This is approximately the same period obtained by using two-thirds of the allowable drift.

Hence, for design purposes,

$$
\begin{aligned}
& T_{\text {design }}=1.8 \mathrm{sec} . \\
& \begin{aligned}
C & =\frac{1}{15 \sqrt{\mathrm{T}}}=\frac{1}{15 \sqrt{1.8}}=0.050 \\
S & =1.2+0.6\left(\frac{\mathrm{T}}{\mathrm{T}_{\mathrm{S}}}\right)-0.3\left(\frac{\mathrm{T}}{\mathrm{T}_{\mathrm{S}}}\right)^{2} \\
& =1.2+0.6\left(\frac{1.8}{1.0}\right)-0.3\left(\frac{1.8}{1.0}\right)^{2}=1.31=0 . ; ! 0.4
\end{aligned}
\end{aligned}
$$

Substituting into Formula (12-1),

$$
\begin{aligned}
V & =Z \operatorname{IKCSW} \\
& =(1.0)(1.0)(0.67)(.050)(1.31) \mathrm{W} \\
V & =.044 \mathrm{~W}
\end{aligned}
$$




$$
\begin{aligned}
& W_{f 1 .}=(122.5 \times 77.5)(.085)+(400 \times 11.5)(.015)=874 \text { kips } \\
& W_{\text {If. }}=(122.5 \times 77.5)(.067)+(400 \times 8.75)(.015)=687 \text { kips } \\
& W=6(874)+687=5930 \text { kips (total dead load) } \\
& V=0.044 \mathrm{~W}=(.044)(5930)=260 \text { kips (total lateral force) }
\end{aligned}
$$

The total lateral force is distributed over the height of the building in accordance with UBC Formulas $(12-5),(12-6)$ and $(12-7)$. See Fig. 4.2.

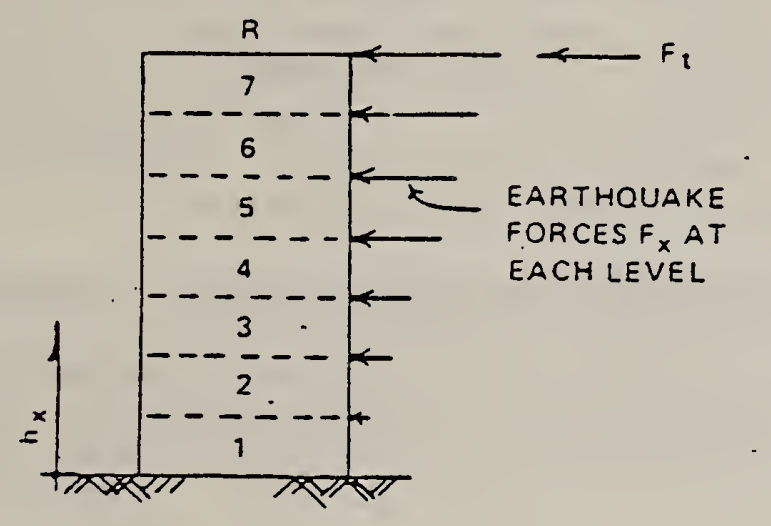

Figure 4.2 Distribution of earthquake forces over height of building.

$$
\begin{aligned}
& V=F_{t}+\sum_{i=1}^{n} F_{i} \\
& F_{t}=0.07 T V=.07(1.8)(260)=33 \text { kips } \\
& F_{X}=\frac{\left(V-F_{t}\right) w_{x} h_{X}}{\sum_{i=1}^{n} w_{i} h_{i}}=\frac{227 w_{x} h_{x}}{\sum_{i=1}^{n} w_{i} h_{i}}
\end{aligned}
$$

The distribution of lateral forces over the height of the building is shown in Table 4-1. 
FROM: Richard M. Simon, Goldberg-Zoino \& Associates, Inc.

a) Both the equivalent iateral force and modal analysis procedures are approximate in themselves. There have been few prototype observations to explore the accuracy of either procedure. The equations contained in Chapter 6 are based solely on analytical studies with almost no prototype or even laboratory verification. Because of the approximate nature of the entire anatysis procedures it is, in my opinion, inappropriate to add an additional level of sophistication to the equations. The SSI equations are so complex as to make me question whether they could be properly applied by the average structural/civil engineer. There are no guidelines provided in the provisions or commentary as to the approximate magnitude of the effect produced by these equations other than the reduced base shear sha 17 in no case be taken Tess than 0.7 times the rigid support base shear. Little guidance is provided in the readily available published literature. Although failure to incorporate. the effects of SSI is in almost all cases a conservative assumption, it is not clear that applying the equations without complete understanding and with potential errors will lead to conservative design forces and displacements.

b) The Tentative Provisions have emphasized the inelastic behavior of structures in response to earthquake loading. The analytical procedures used as the basis of the Chapter 6 provisions assume a linear response for the superstructure which is inconsistent with the general philosophy of the Tentative Provisions.

Fror: Henry J. Degenkolb

1. Chapter 6 - Soil-Structure Interaction

First, it must be understood that $I$ was in the minority on this when it was decided to include the soil-structure interaction provisions in ATC 3-06. However, I'm also in the spot of defending them. I do believe that in some (many?). structures the soil-structure relationship is very important. It is so complex, however, that little is known about it and almost everything we do know about $1 t$ is from theory and not from measurements or observations especially at the level of strains associated with earthquake motions. Even the theory has only been advanced for certain unique cases such as mat foundations, etc. Therefore, I cannot honestly argue with the reasons that Simon presents under (a) or (b). 


\subsection{ROSTER}

\section{COMMITTEE 3: Foundations}

American Society of Civil Engineers

Mr. James G. LaBastie

6252 Powell Road

Parker, Colorado 80134

Phone: $303-771-8641$

Association of Soil and Foundation Engineers

Mr. Richard Simon (Chairman)

Goldberg, Zoino, Dunnicliff \& Assoc., Inc.

30 Tower Road

Newt on Upper Falls, Massachusetts 02164

Phone: 617-969-0050

\section{Interagency Committee on Seismic Safety in Construction}

Mr. Joseph V. Tyrrel1

Director, Civil/Struc. Div.

Naval Facilities Engineering Comnd.

200 Stovall Street

Alexandria, VA 22332

Phone: 202-325-0064

Structural Engineers Association of California

Mr. William Travis

7851 Mission Center Court

Suite 250

San Diego, California 92108

Phone: $714-291-2800$

Applied Technology Council

Mr. Henry Degenkolb

H. J. Degenkolb \& Associates

350 Sansome Street

San Francisco, CA 94104 
Committee 3 (continued)

Building Seismic Safety Council

Mr. Leroy Crandall, President

L. Leroy Crandall and Associates

711 North Alvarado Street

Los Angeles, California 90026

Phone: $213-413-3550$

National Bureau of Standards

Mr. Lawrence Salomone

Secretariat

Committee 3, Foundations

National Bureau of Standards

Rm. B162, B1dg. 226

Washington, D.C. 20234

Phone: 301-921-3128 
NBS-IIAA (REV. 2-78)

\begin{tabular}{|c|c|c|}
\hline $\begin{array}{l}\text { U.S. DEPT. OF COMM. } \\
\text { BIBLIOGRAPHIC DATA } \\
\text { SHEET }\end{array}$ & $\begin{array}{l}\text { 1. PUBLICATION OR REPORT NO. } \\
\text { NBSIR } 80-2111-3\end{array}$ & 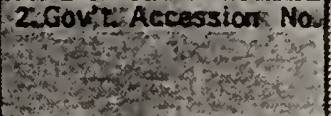 \\
\hline
\end{tabular}

4. TITLE AND SUBTITLE

Review and Refinement of ATC 3-06 Tentative Seismic Provisions

5. Publication Date

Report of Technical Committee 3: Foundations

7. $A U T H O R(S)$

Lawrence A. Salomone

9. PERFORMING ORGANIZATION NAME AND ADDRESS

NATIONAL BUREAU OF STANDARDS

DEPARTMENT OF COMMERCE

WASHINGTON, DC 20234

12. SPONSORING ORGANIZATION NAME AND COMPLETE ADDRESS (Streot, City, State, ZIP)

Federal Emergency Management Agency

Washington, DC 20472

October 1980

6. Performing Organization Code:

8. Performing Organ. Report No.

10. Project/Task/Work Únit No.

11. Contract/Grant No.

13. Type of Report \& Period Covered

Final

14. Sponsoring Agency Code

15. SUPPLEMENTARY NOTES

Document describes a computer program; SF-185, FIPS Software Summary, is attached.

16. ABSTRACT (A 200-word or less factual summary of most significant information. If document includos a significant babliography or literature survey, mention it here.)

The Tentative Provisions for the Development of Seismic Regulations for Buildings were developed by the Applied Technology Council to present, in one comprehensive document, current state-of-knowledge pertaining to seismic engineering of buildings. The Tentative Provisions are in the process of being assessed by the building community.

This report is one of a series of reports that documents the deliberations of a group of professionals jointly selected by the Building Seismic Safety Council and the National Bureau of Standards and charged with reviewing the Tentative Provisions prior to conducting trial designs.

This report documents the activities of Technical Committee 3: Foundations. Other committee reports are similarly available. The task of Technical Committee 3 was to review and refine Chapter 6, Soil-Structure Interaction and Chapter 7, Foundation Design Requirements in the ATC report (NBS SP-510) entitled, "Tentative Provisions for the Development of Seismic Regulations for Buildings." Two meetings were held. The opening meeting of the group was on December 11, 1979, and the concluding meeting was on February 5, 1980. The minutes of these meetings and the findings/recommendations of Technical Committee 3 are presented in this report. These recommendations were made to the parent group, the Joint Committee on Review and Refinement, and their action on these recommendations is documented in a companion report.

17. KEY WORDS (six to twelve entries; alphabetical order; capitalize only the first letter of the first key word unless a proper name; separated by semicolons)

Buildings; design; earthquakes; engineering; foundations; professional practice; provisions; soil-structure interaction; standards

18. AVAILABILITY
XXXunlimited

For Official Distribution. Do flot Release to NTIS

Order From Sup. of Doc., U.S. Government Printing Office, Wasinıngton, DC 20402, SD Stock No. SNO03-003-

X] Order From National Technical Information Service (NTIS), Springfield, VA. 22161
19. SECURITY CLASS (THIS REPORT)

UNCLASSIFIED (THIS PAGE)
21. NO. OF

PRINTED PAGES

53

22. Price

$\$ 8.00$

UNCLASSIFIED 

